\title{
Quantitative-geomorphological and Environmental-historical Impact on the Ecological Soil Depth; Northwestern Croatia
}

\author{
S. Lozić, B. Fürst-Bjeliš, D. Perica
}

\begin{abstract}
With regard to its geographical position, role and significance, North-Western Croatia represents the key area of the Republic of Croatia. It is the area of a long-lasting continuity of population and a great, although regionally differentiated, agrarian density. A long and intensive pressure on the environment is one of the most important factors which have influenced the ecological soil depth. Because of the presumed influence of the quantitative geomorphological features (average height, relative height, slope length, length and relative height index, inclination, surface regularity, expositions) and lithology features (rock strength coefficient) on the volume and intensity of slope processes, a multiple regression analysis has been carried out for the dependent variable of ecological depth and the quoted variables as independent assessors.
\end{abstract}

Key words: North-Western Croatia, quantitative geomorphology, soil analysis, regression analysis, human impact, environmental history

\section{Kvantitativno-geomorfološki i historijsko-geografski utjecaji na ekološku dubinu tla; Sjeverozapadna Hrvatska}

Sjeverozapadna je Hrvatska ključno područje Republike Hrvatske s obzirom na geografski položaj te na svoju ulogu i značenje. Sjeverozapadna Hrvatska prostor je dugotrajnog kontinuiteta naseljenosti i velike, iako regionalno diferencirane, agrarne gustoće. Dugotrajan i intenzivan pritisak na okoliš svakako je jedan od značajnijih faktora koji su utjecali i na ekološku dubinu tla. Zbog pretpostavljenog utjecaja kvantitativnih geomorfoloških značajki (srednja visina, relativna visina, dužina padina, indeks dužine i rel. visine, nagib, regularnost površine, ekspozicije) i značajki litologije (koeficijent čvrstoće stijena) na opseg i intenzitet derazijskih procesa, provedena je multipla regresijska analiza za zavisnu varijablu ekološke dubine te navedene varijable kao nezavisne procjenitelje.

Ključne riječi: Sjeverozapadna Hrvatska, kvantitativna geomorfologija, analiza tla, regresijska analiza, ljudski utjecaj, historijska-geografija okoliša

\section{INTRODUCTION}

With regard to its geographical position, role and significance, North-Western Croatia represents the key area of the Republic of Croatia. Its area amounts to approximately $19,665 \mathrm{sq} \mathrm{km}$, i. e. $35 \%$ of the area of the Republic of Croatia (Fig. 1). The researched area is somewhat smaller, because it covers denudational-tectonic and denudational-accumulation relief, that is the slopes of inclination $>2^{\circ}$. 

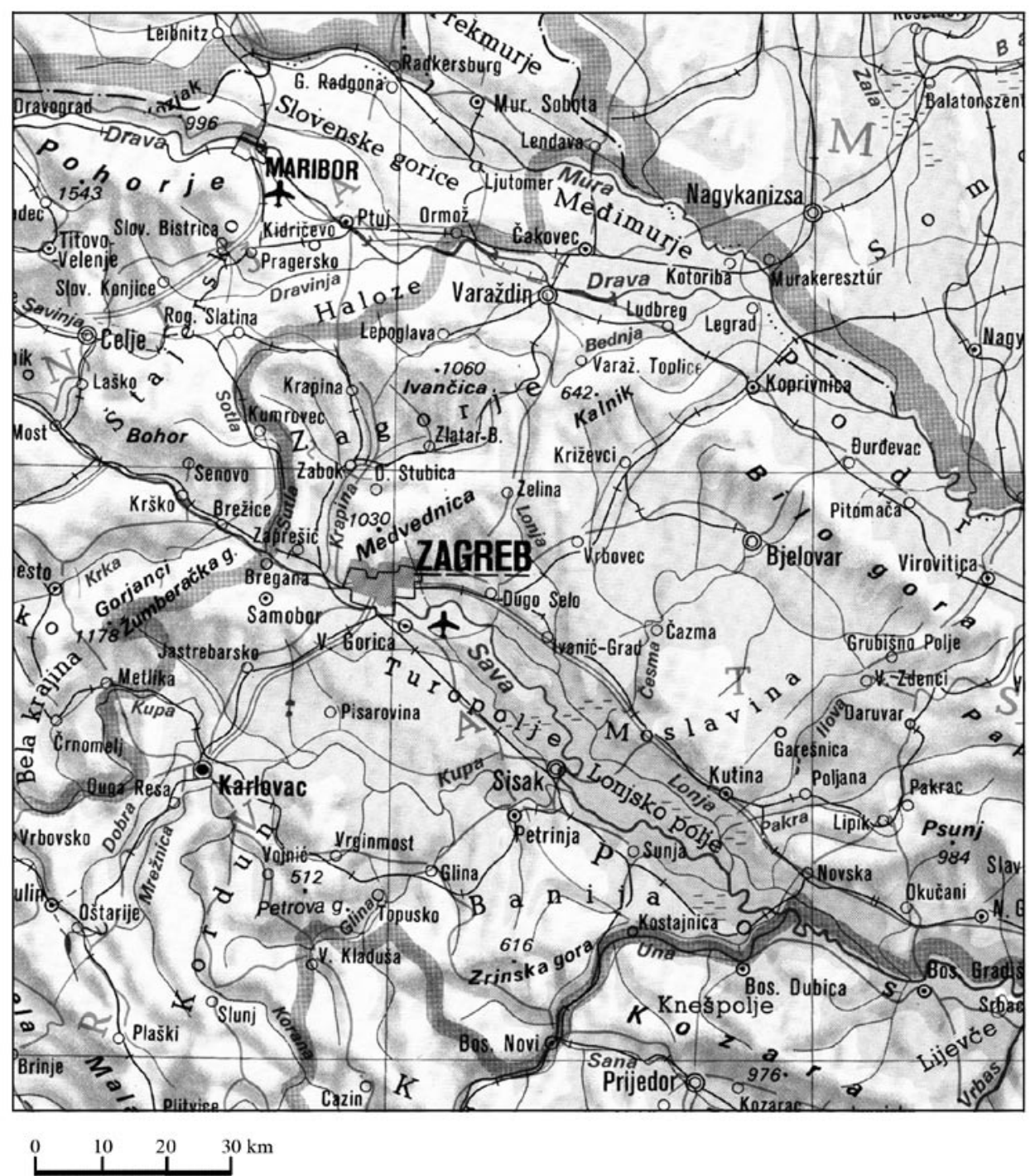

Fig. 1 North-Western Croatia

Sl. 1. Sjeverozapadna Hrvatska

North-Western Croatia is the region of a long-lasting population continuity, and great, although regionally differentiated, agrarian density. A long and intensive pressure on the environment is, surely, one of the most significant factors which have influenced ecological soil depth. Land clearance and subsequent agricultural intensification typically led to soil erosion and nutrient depletion. Regionally differentiated land use and agrarian density in relation to geomorphological characteristics influenced the variability of ecological depth of the soil. 
Because of the presumed influence of the quantitative geomorphological features (average height, relative height, slope length, length and relative height index, inclination, surface regularity, expositions) and lithology features (rock strength coefficient) on the volume and intensity of slope processes, a multiple regression analysis has been carried out for the dependent variable ecological depth and the quoted variables as independent as assessors. Besides the influence of the included variables, the influence of some other factors is also undeniable: primarily human influence, e.g. that of endogenous geologic processes or vegetation cover. The aim of the analysis is to answer the question whether and to what degree the independent variables are significant assessors of the probability of more frequent slope processes on the basis of the present condition, and which are supposed to be reflected by the dependent variable of ecological soil depth.

\section{FORMER RESEARCH}

Morphometric data about relief are included in a significant number of works dealing with slope processes, i. e. soil erosion, hazard and risk. In 1956, J. W. Pallister analyses the slope development in eastern Africa, considering not only the slope elements, but also the influence of climatic and pedologic factors. M. A. Carson and d. J. Petley (1970) research the marginal values, which influence the slope stability in the region of Devon. Japanese scientists deal with the same problems on the example of the island of Kyushu (Y. Matsukura, S. Hayashida and A. Maekado, 1984). V. Prasuhn and d. Schaub (1991) consider erosion dynamics on loess and clay soils. M. Julian (1991) on the example of the French Western Alps brings into connection slope processes (rock-fall and rock-slump) and water infiltration. L. A. Lewis (1991) brings into connection agricultural products, topography and soil degradation in western Rwanda. J. C. Doornkamp (1993) considers the erosion risk connected with the processes in clay soils, and D. C. Jones in the same year publishes a work about the causes of the slope stability variability. M. J. Bovis (1993) deals with the slope processes and research techniques in Canada. S. M. Brooks, K. S. Richards and M. G. Anderson in their study of slope development (1993) research the relation among soil, pedogenesis and slope stability. J. J. Ibáñez, A. Pérez-Gonzáles et al. consider the evolution of the relief forms developed by fluvial dissection partly on the basis of morphometrical criteria and geomorphological, pedologic and phytocenologic consequences. I. Bárányi i G. Mezösi (1995) analyse ecological characteristics of the doline types in northern Hungary. R. J. Allison (1996) deals with slope processes, especially landslides and stability models. T. Oguchi specifies the quantity of the eroded material in the Quarternary deduced from the classification of relief forms and morphometric indicators on the example of Japan (1996).

As to the land-slide hazard research, several indirect methods have been developed by various authors. Besides other parameters, they include geomorphological, i. e. morphometric ones. So Neuland (1976, according to Mihalić, Stanić, 1995) develops a model on the basis of morphometric, geotechnological, hydrogeological and vegetation parameters with the purpose of anticipation of slope sensitivity to land-slide; Carrara et al. (1978, according to Mihalić, Stanić, 1995) in the framework of the national project in Italy consider the risk of erosion on the basis of geomorphological, hydrological, lithologic, 
vegetation and anthropogenic parameters. In 1983, they research the existing land-slides in the southern regions of Italy on the basis of the mentioned criteria. Yin and Yan (1988, according to Mihalić, Stanić, 1995) develop the spatial model for land-slide anticipation on the basis of geomorphological and lithologic parameters. Siddle et al. (1991, according to Mihalić, Stanić, 1995) work out an algorithm, which expresses the terrain sensibility to land-slide on the basis of geomorphological, hydrogeological and anthropogenic parameters. The analyses and statistical procedure used by the mentioned authors include the analyses of the main directions, multivariate statistical methods, information theory and empiric methods (S. Mihalić, B. Stanić, 1995). C. Rouse, P. Styles and S. A. Wilson (1991) analyse the acoustic emissions of two land-slides in Southern Wales and come to the conclusion that it is possible to identify a potential instability. A. M. Harvey and A. Calvo-Cases (1991) analyse the slope processes interaction on the example of gullies, and H. Barsch and R. Weisse (1991) consider the recent changes of relief and soil in Germany. In 1997 K. Vandaele, J. Poesen, J. R. Marques de Silva, G. Govers and P. Desmet research the factors having influence on slope processes (gullying) by means of air-photographs.

In more recent time there is a large number of relief researches based on the digital model of relief (T. W. Gardner, K. C. Sasowsky, R. L. Day, 1990).

Former researches mainly affirm the assumption of the influence of quantitative geomorphological and lithologic features on the volume and intensity of slope processes, but we must point out that in most of analyses morphological indicators are taken separately, that is only bivariate analyses are mostly in question. For example, the research of the relation among slope morphology, depth of regoliths and emergence of land-slides in New Zealand, carried out by DeRose (1996), proved, on the basis of regression analysis, a significant correlation between the average slope inclination and the average depth of regoliths. The author points to the necessity of inserting a larger number of morphological relief variables into the regression equation because of a better prediction.

Besides the mentioned research dealing mostly with abiotic factors of natural environment, it is necessary to point to the importance of considering the specific human impact on environment.

Relation between man and environment is the main topic of historical geography, cultural ecology as a branch of cultural geography, and in some last thirty years, of a new discipline which is stronger and stronger on scientific scene: environmental history. Its basic preoccupations are deforestation as a global process (Williams, 2000), and various forms of degradation and environmental changes through time (Butlin, Roberts, 1995; Head, 2000: Powell, 2000; Simmons, 1998), as well as the study of the relation model between man and environment through time (Mannion, 1995; Simmons 1996, 1998; Simmons, Mannion, 1995).

\section{RESEARCH METHODS}

In the sampling phase the homogenous land areas representing slopes were singled out on the orohydrographical maps to the scale of 1:100 000 on the basis of the watersheds and talwegs, with the additional criterion of the slope exposition changes. In that way the 
samples of 4,495 slopes approximately 1-10 sq km large were obtained. Because of an easier statistical interpretation, but also because of a separate analysis possibility, the data were systematised according to dominant geomorphological mesoregions.

After this phase the average height sampling was carried out, as well as the samplings of relative height and slope length (profiles), average inclinations, surface regularity, exposition, average ecological depth and strength coefficient (land areas). Length index and relative height index, as well as additional inclination indicator, were calculated later on. A data basis of 40,455 units (4,495 samples and 9 variables) was established as the result of the carried out samplings and measurements and as the basis of regression analysis.

Multiple regression analysis, especially the models of the multiple linear regression, has been heavily applied in research, descriptions and interpretations of various phenomena. In the quantitative geomorphological research there is a frequent necessity to analyse large quantities of spatial data, which, because of their compound structure and complex mutual relations cannot be satisfyingly explained by only one independent variable (Lozić, 2000).

As it has already been mentioned in the introductory part, the multiple linear regression method has been used in this work as a criterion of defining the features of correlation among variables. It was also used as a criterion of defining the relative importance of variables' impact on the prediction of the ecological soil depth, on the assumption that the variables significantly influence the volume and intensity of exogenous morphological processes, which is reflected on soil features.

Two important aims of this analysis arise from all this: a) determination of significance level of the chosen variables, on the basis of which we decide whether all variables will be used in the analysis (that is in the possible further analyses), b) determination of absolute and relative importance of particular variables as indicators of character, volume and intensity of certain processes in the morphological relief formation. In this case it relates to the prediction of the ecological soil depth, which can be useful in the possible later evaluation as an additional criterion, especially in the cases where we come upon certain doubts in the relief types classification into particular value categories. It is essential to point out that the criterion identity for all variables is of great importance, so, before analysing, it is necessary to turn them to the standardised $\mathrm{Z}$ values (standard deviation).

When more than three independent variables are introduced into a regression model, the regression equation runs as follows:

$$
Y=a+b_{1} \cdot x_{1}+b_{2} \cdot x_{2}+\ldots b_{\mathrm{n}} \cdot x_{\mathrm{n}}
$$

This equation represents the equation of multidimensional hyperplane which cannot be geometrically presented (V. Serdar, I. Šošić, 1981).

After the calculation of the regression curve equation, the value is being appraised for Y, in this case for the dependent variable of ecological depth. Then we calculate the deviations of the dependent variable's original values from its estimated ones. These deviations are being squared and summed up in order to get the sum of squares of the unexplained and 
residual deviations ${ }^{1}$. If the residual deviation is zero, the original values of the dependent variable will be on the regression direction, and it means that the regression direction's value will be a completely precise estimate of the dependent variable. If the residual deviation increases, the original values of the dependent variable will deviate more and more from the regression direction, and the regression direction`s values will give a weaker and weaker estimate of the dependent variable. In other words, the residual deviation can be a good measure of estimate precision of the dependent variable by means of the regression line, but because there are many such deviations (all pairs of values), it is necessary to express this indicator by one number. This number is made by the average deviation, that is by the arithmetic mean of the deviation squares, according to the expression:

$$
\sum_{\mathrm{i}=1}^{\mathrm{N}}\left(Y_{\mathrm{i}}-Y\right)^{2}=\sum_{\mathrm{i}=1}^{\mathrm{N}}\left(Y_{\mathrm{i}}-Y\right)^{2}+\sum_{\mathrm{i}=1}^{\mathrm{N}}\left(Y_{\mathrm{i}}-Y_{\mathrm{i}}\right)^{2}
$$

which marks the equation of variance analysis. It shows that the sum of the squares of deviations of the dependent variable's original values from their arithmetic mean consists of two parts: of the sum of the squares of the values` deviations estimated by means of the regression direction and arithmetic mean, and of the sum of the squares of deviations of the dependent variable`s original values from the values of the same variable estimated by means of the regression direction.

If the left and right sides of the equation are divided by the number of observations, one gets the explained and unexplained parts of the variance, according to the expression:

$$
\begin{aligned}
& \frac{\sum_{\mathrm{i}=1}^{\mathrm{N}}\left(Y_{\mathrm{i}}-Y\right)^{2}}{\mathrm{~N}}=\frac{\sum_{\mathrm{i}=1}^{\mathrm{N}}\left(Y_{\mathrm{i}}-Y\right)^{2}}{\mathrm{~N}}+\frac{\sum_{\mathrm{i}=1}^{\mathrm{N}}\left(Y_{\mathrm{i}}-Y_{\mathrm{i}}\right)^{2}}{\mathrm{~N}} \\
& \text { or: }: \sigma^{2}=\sigma_{\mathrm{p}}{ }^{2}+\sigma_{\mathrm{np}}{ }^{2}
\end{aligned}
$$

The smaller is the unexplained part of the variance, the more precise is the estimate of the dependent variable by means of the regression direction.

\section{ENVIRONMENTAL - HISTORICAL SETTING}

According to the Simmons 'regional division of Europe for environmental history (Simmons, 1998), Croatia enters the broad Mediterranean region, which includes the circum Mediterranean countries as well as south-eastern Europe. Those regions are defined according to the prevailing environmental opportunities, constraints and impact in relation to the predominant human economies, which have occupied the European space. As each economy type affected the environment in a specific way, each phase left some traces of its existence in today`s landscape. 
The broad Mediterranean region is characterised by early influence of agriculture and fast soil loss from high slopes. Heavy grazing has produced poor swards, while both processes were accompanied by considerable deforestation. All main crops required cleared land, much of which might be on slopes that eroded easily. An equally high profile was generated by the impact of pastoralism on the hills (Simmons, 1998, 353). The hilly and mountainous nature of the area conditioned the translocation of soil from the upper slopes to the valleys. Consequently, the principal environmental change was marked by soil erosion and forest change.

General determinants of the environment of North-Western Croatia are a relatively complex relief structure with domination of fluvial and fluvio-denudational relief forms, a more humid version of moderately continental climate, surface outflow, vegetation climax of sessile oak and hornbeam (Querco-carpinetum Croaticum Horv.), that is a lowland paraclimax of common oak (Genisto-elatae-Quercetum roboris Horv.), and pseudogley, semigley, alluvial and marshy-gley types of soil. Besides general determination of environment, there are also interior relations and differences in its particular elements which essentially determine spatial differences in type and intensity of human impact.

Lowland zones, flooded periodically, have been used for centuries as the areas of extensive cattle raising, that is forest pastures in oak forests. At the same time, those areas are very unfavourable for agriculture (Fuerst-Bjeliš, 1996). Namely, the greatest danger is frequent frost just in concave relief forms, where there is an inflow of cold air, and no outflow. These are humid lowlands, bottoms and lower parts of slopes of narrow closed valleys, intermontane basins and closed, wide plane valleys. Here temperatures can be to $6^{\circ} \mathrm{C}$ lower in relation to the surrounding terrain (Otorepec, 1980). Therefore, low and humid parts of North-Western Croatia are favourable for growing only a very limited choice of the most resistant cereals., That is why they are used for pasture to the fullest extent.

The most intensive environmental human impact is in the zones of hilly regions and foothills by mountain ranges, which, because of different environmental elements, provide different conditions for the corresponding polyculture. However, besides general favourableness of these zones, some general patterns in preferability of particular environmental elements have been established, as well as of particular quantitative geomorphological features. This primarily relates to height, slope inclination and exposition, where the areas of average and less height, smaller slope inclination and southern exposition are generally more valuable (Fuerst-Bjeliš, 1996). The impact intensity on soil through the polycultural form of agriculture and wine-growing, that is ploughing, slope cutting and forest clearing, have a greater impact on the soil erosion process, as well as on relocation of the slope material from higher to lower parts of slopes, and so conditions variability of the ecological soil depth. Consequently, in these areas the factor of human impact on ecological soil depth is by all means one of the most significant, and is surely the variable accounting for a significant part in the unexplained variance share. 


\section{QUANTITATIVE GEOMORPHOLOGICAL VARIABLES AND LITHOLOGY VARIABLE}

For this work the average height of each slope has been defined as the average value of the total range of contours on a certain slope by direct measurement on a map, according to the formula $\mathrm{H}_{\mathrm{sr}}=\left(\mathrm{H}_{\max }+\mathrm{H}_{\min }\right) / 2$. In that way we obtained representative values which represent the average conditions of intensity of the slope climate processes.

The relative height was determined for each sample (slope) as difference between the maximum and minimum height $(\Delta \mathrm{h})$, which represents a useful information about a wider area 's dissection, but also a potential indicator of slope processes (which will be more exactly determined by bringing this parameter into a relation with slope length).

As slopes are the basic relief element, determination of slope inclinations is one of essential elements of relief analysis. Slope inclination is defined by the angle between the terrain surface and horizontal plane.

The relation between slope length and relative height $(\mathrm{d} / \Delta \mathrm{h})$ was used as an additional more precise assessor of slope inclinations. In that way the obtained values quantify the average inclinations values on each particular slope, which are categorised into 6 categories.

The surface regularity parameter can be an indicator of endogenous geological processes' influence, but also of abrupt changes in lithological rock structure. In this work this parameter is expressed as the number of inclination changes on a particular slope. It is necessary to point out that this is only a general indicator, which does not take into consideration all inclination number changes on the researched surfaces, but only those which are markedly visible in the relief.

Exposition can be defined as a position of a relief form surface, whose contour direction is vertical on the direction of a particular world side, i. e. exposition (exposure) is orientation of slopes, river and stream valleys in relation to the world sides or horizon plane, i. e. towards the Sun (Šegota, Filipčić, 1996).

Modified indexes of exposition value adjusted to a certain research aspect, i. e. to the estimate of relative influence of climatic elements on the character and intensity of denudation processes.

It is known that relief modifies to a significant extent the wind's influence on soil, precipitation stability, vegetation and whole ecosystem. However, it can hardly be quantified without field measurements, because the air current horizontal component adapts itself to the relief changing direction and circulation speed in local frameworks. Consequently, a completely exact spatially explicit model of slope exposure to wind cannot be static, but must include the wind direction changes over certain relief forms (Antonić, 1996). With regard to the size and scale of the researched area, it is necessary to make a compromise and accept the static orientation of "sources" of the rain-bearing wind, and consistently with that, the analysis and exposure evaluation, especially for various directions with the step of $45^{\circ}$ (eight standard directions of wind). 
S. Lozić, B. Fürst-Bjeliš, D. Perica - Quantitative-geomorphological and Environmental-historical Impact on the Ecological Soil Depth; Northwestern Croatia

Tab. 1 Ecological soil depth and land use of soil mapping units

Tab. 1. Ekološka dubina tla i način korištenja kartiranih jedinica tla

\begin{tabular}{|c|c|c|c|}
\hline $\begin{array}{c}\text { No of soil } \\
\text { mapping units }\end{array}$ & $\begin{array}{l}\text { Dominant soil } \\
\text { mapping units }\end{array}$ & Land use & $\begin{array}{l}\text { Ecological soil } \\
\text { depth in } \mathrm{cm}\end{array}$ \\
\hline 7 & Rigosol on loess & vineyards & $50-100$ \\
\hline 8 & Luvisol on loess, typical & arable land & $70-150$ \\
\hline 10 & $\begin{array}{l}\text { Luvisol on loess, } \\
\text { pseudogleyic }\end{array}$ & $\begin{array}{l}\text { arable land, } \\
\text { forests } \\
\text { orchards }\end{array}$ & $70-150$ \\
\hline 11 & $\begin{array}{l}\text { Luvisol on marl and soft } \\
\text { limestone, typical }\end{array}$ & $\begin{array}{l}\text { forests, arable } \\
\text { land and vineyards }\end{array}$ & $50-150$ \\
\hline 14 & Terra rossa, luvic & $\begin{array}{l}\text { arable land and } \\
\text { forests }\end{array}$ & $70-200$ \\
\hline 15 & $\begin{array}{l}\text { Terra rossa luvic and typical, } \\
\text { deep }\end{array}$ & arable land and vineyards & $50-100$ \\
\hline 17 & $\begin{array}{l}\text { Rendzina on marl (flysch) or } \\
\text { soft limestones }\end{array}$ & $\begin{array}{l}\text { vineyards, arable land and } \\
\text { forests } \\
\text { forests }\end{array}$ & $30-150$ \\
\hline 18 & Luvisol 1 on loams, typical & forests and grasslands & $50-100$ \\
\hline 19 & $\begin{array}{l}\text { Distric Cambisol on loess and } \\
\text { Holocene sediments }\end{array}$ & $\begin{array}{l}\text { forests, arable land and } \\
\text { orchards }\end{array}$ & $50-150$ \\
\hline 21 & $\begin{array}{l}\text { Eutric Cambisol on flysch or } \\
\text { soft limestone }\end{array}$ & arable land and vineyards & $50-100$ \\
\hline 24 & Distric Cambisol on clastites & arable land and forests & $50-90$ \\
\hline 25 & Calcocambisols & arable land and forests & $50-120$ \\
\hline 26 & $\begin{array}{l}\text { Pseudogley on planated } \\
\text { surface }\end{array}$ & arable land and forests & $40-70$ \\
\hline 27 & $\begin{array}{l}\text { Pseudogley on planated } \\
\text { surface }\end{array}$ & arable land and forests & $40-70$ \\
\hline 28 & Slope pseudogley & forests and arable land & $70-150$ \\
\hline 29 & Slope pseudogley & forests and arable land & $50-200$ \\
\hline 32 & $\begin{array}{l}\text { Luvisol typical and acric on } \\
\text { limestone and dolomite }\end{array}$ & $\begin{array}{l}\text { arable land } \\
\text { and forests }\end{array}$ & $50-200$ \\
\hline 33 & $\begin{array}{l}\text { Distric Cambisol on relict } \\
\text { terra rossa }\end{array}$ & $\begin{array}{l}\text { forests, arable land and } \\
\text { grasslands }\end{array}$ & $70-150$ \\
\hline 41 & Fluvisol & $\begin{array}{l}\begin{array}{l}\text { forests (arable land) } \\
\text { grasslands }\end{array} \\
\end{array}$ & $50-120$ \\
\hline 43 & \begin{tabular}{|l} 
Eugley, partly \\
hydromeliorated
\end{tabular} & $\begin{array}{l}\text { forests, arable land and } \\
\text { grasslands }\end{array}$ & $20-90$ \\
\hline 50 & \begin{tabular}{|l|} 
Distric Cambisol on \\
metamorphites and clastites \\
\end{tabular} & forests and grasslands & $40-80$ \\
\hline 53 & Eutric Cambisol on eruptives & forests & $30-80$ \\
\hline 59 & $\begin{array}{l}\text { Luvisol on limestones } \\
\text { and dolomites }\end{array}$ & forests & $50-90$ \\
\hline 62 & $\begin{array}{l}\text { Rendzina on dolomite } \\
\text { and limestone }\end{array}$ & forests and grasslands & $20-50$ \\
\hline 63 & Brunipodzols & forests & $40-100$ \\
\hline
\end{tabular}


Regarding the known facts about influence of particular expositions on the erosion of the surface rock structure in situ, and about the exposure (sheltered condition ) to the influence of humid air masses, that is to a more intensive activity of precipitation, corresponding exposition indexes have been assigned to the cardinal and secondary points of the compass.

The biggest exposition indexes (0.750) were assigned to the slopes exposed towards the north and north-east, on which the influence of precipitation and temperature amplitude is least prominent. Eastern and north-eastern expositions are somewhat less favourable (0.500). The slopes exposed towards the west and south-west are relatively unfavourable $(0.250)$, while the slopes of southern and south-western expositions are the least favourable (0.125).

As determination of the quantitative lithological parameters for all mechanical features of rocks surpasses the volume of this work, the strength coefficient has been chosen as a representative indicator. The reason is that on the basis of this indicator we can provide a general estimate of the character and intensity of the exogenous geomorphological processes activity.

Rock strength can be defined as the resistance given by rock mass when it is exposed to pressure, stretching, bending and sliding ${ }^{2}$.

The dependent variable of ecological soil depth has been quantified on the basis of Pedological Map of Croatia, 1: 300000 (1996) (Tab. 1.).

\section{MULTIPLE REGRESSION ANALYSIS OF CORRELATION BETWEEN ECOLOGICAL SOIL DEPTH AND OTHER VARIABLES ON THE EXAMPLE OF NORTH-WESTERN CROATIA}

The regression analysis for the dependent variable of ecological soil depth for NorthWestern Croatia (Tab. 2.) has resulted in a relatively high regression coefficient $(0.705)$ and determination coefficient $\mathrm{R}^{2}=0.5$. It means that about $50 \%$ of the variance of the NorthWestern Croatia`s slope system was explained by a regression model. It is important that all variables included in the analysis are significant assessors of the ecological soil depth, except the variable expositions ' index ( $t$ - the significance test of regression coefficients with $\mathrm{p}<0.05)$, but the sign of the standardised beta coefficient is the correlation direction indicator.

Graphic presentation of the relation between the values of the dependent variable of ecological soil depth and independent variables is presented in the Fig. 2. Variability is negligible, but mainly homogenous around the direction of hypothetic equality of sampled and estimated values.

The analysis of residual and by the model estimated values (deviation of particular points from the regression direction) points to an approximately linear relation between the dependent and independent variables, i. e. a "cloud" of values is rather homogenously distributed around the central direction (Fig. 3.). 
S. Lozić, B. Fürst-Bjeliš, D. Perica - Quantitative-geomorphological and Environmental-historical Impact on the Ecological Soil Depth; Northwestern Croatia

Tab. 2 Regression indicators for the dependent variable: ecological soil depth

Tab. 2. Regresijski pokazatelji za ovisnu varijablu: ekološka dubina tla

\begin{tabular}{|c|c|c|c|c|c|c|}
\hline \multicolumn{7}{|c|}{$\begin{array}{l}\text { Regression Summary for dependent variable: ECOLOGICAL I } \\
R=.70589913 \quad \mathrm{R} 2=.49829358 \quad \text { Adjusted R20 } .49739888 \\
\mathrm{~F}(8,4486)=556.94 \mathrm{p}>0.0000 \text { Std.Error of estimate: } .70893\end{array}$} \\
\hline $\mathrm{N}=4495$ & BETA & $\begin{array}{c}\text { St. Error } \\
\text { of Beta }\end{array}$ & $\mathrm{B}$ & $\begin{array}{c}\text { St. Error } \\
\text { of B }\end{array}$ & $t(4486)$ & $\mathrm{p}$ - level \\
\hline Intercpt & & & 0,00106807 & 0,0105752 & 0,100998 & 0,919556 \\
\hline SREDVIS & $-0,21558065$ & 0,015971929 & $-0,215582218$ & 0,0159720 & $-13,49747101$ & 0,000000 \\
\hline RELVIS & 0,05999490 & 0,024621575 & 0,05999257 & 0,0246206 & 2,436680 & 0,014861 \\
\hline DUZINA & $-0,11489230$ & 0,021433408 & $-0,11489001$ & 0,0214330 & $-5,36043102$ & 0,000000 \\
\hline DUZRVIS & 0,13065663 & 0,020990868 & 0,13082191 & 0,0210174 & 6,224451 & 0,000000 \\
\hline NAGIB & $-0,20169764$ & 0,015499866 & $-0,202779206$ & 0,0155830 & $-13,01286299$ & 0,000000 \\
\hline REG.POV. & 0,05146167 & 0,010851551 & 0,05170022 & 0,0109019 & 4,742334 & 0,000002 \\
\hline EKSPO & $-0,01990164$ & 0,010628382 & $-0,019993137$ & 0,0106772 & $-1,872500$ & 0,061202 \\
\hline LITO & $-0,35202266$ & 0,013819875 & $-0,351641791$ & 0,0138049 & $-25,47220264$ & 0,000000 \\
\hline
\end{tabular}

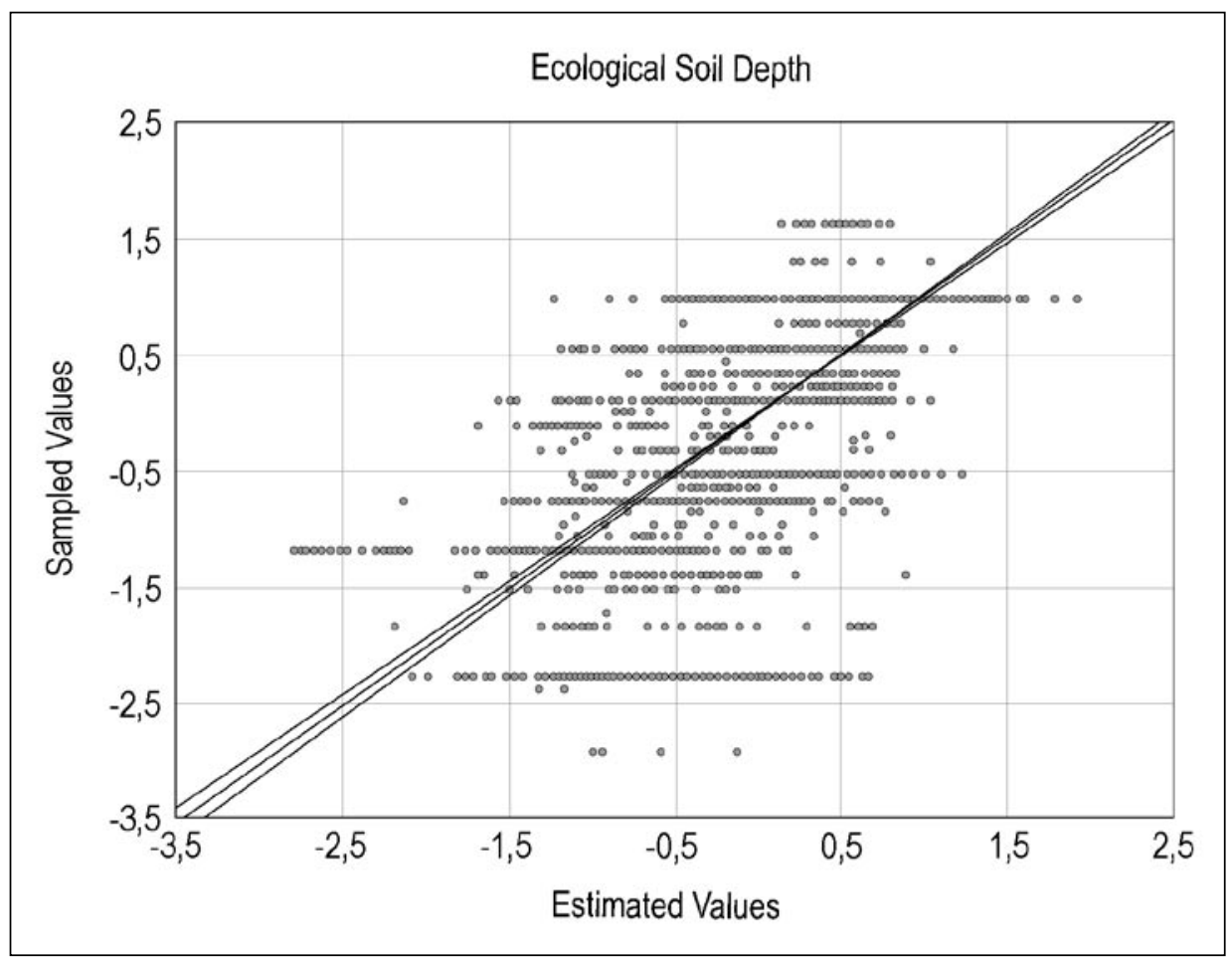

Fig. 2 Relation between sampled and by the model estimated values

Sl. 2. Odnos uzorkovanih i modelom procjenjenih vrijednosti 


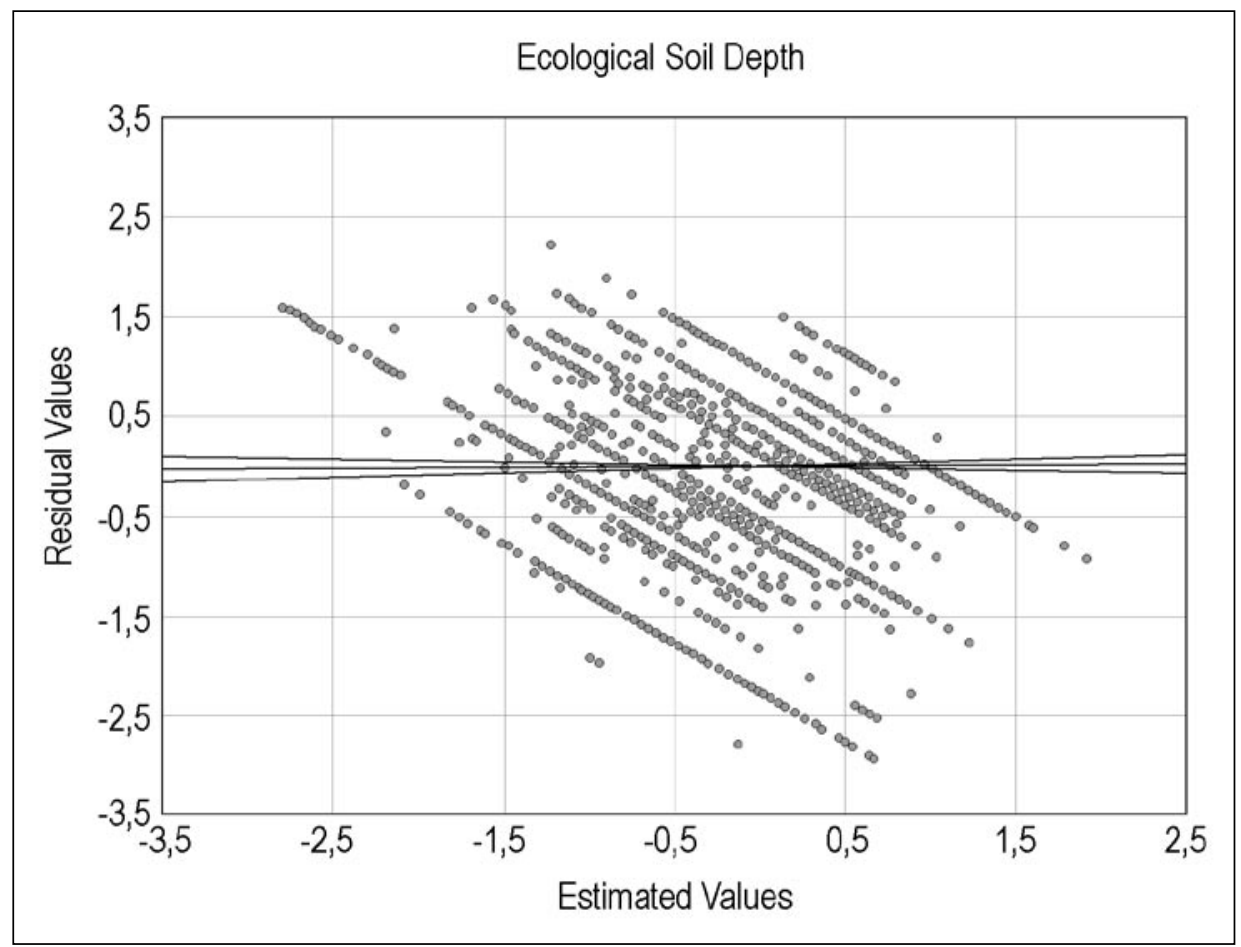

Fig. 3 Relation between residual and by the model estimated values Sl. 3. Odnos rezidualnih i modelom procjenjenih vrijednosti

Dominant influence of lithology variables in the estimate of the ecological soil depth in North-Western Croatia is noticable, then the influence of the average height and inclinations on the ecological depth prediction, while the other variables` share, although significant, is marked to a lesser extent (variables of relative height and surface regularity) (Tab.2., Fig.4.).

The largest relative share of lithology, i. e. of the strength coefficient variable (with negative sign, which means that the soil depth decreases with the increase of the rock strength) is not expected, because the influence of the rock mass, i. e. of the parent substratum on pedogenesis is of special importance. The variables of inclination and average height, which represent a strengthened intensity of gravitational slope processes and intensified precipitation influence, are negatively correlated with the ecological soil depth, which means that the average height decreases with inclination decrease, which conditions the increase of the ecological soil depth. Similar, but to a somewhat lesser degree, is with the slope length, i. e. with the slope length increase, the volume and intensity of gravitational processes and surface water outflow increases, too, which is connected with the soil depth.

Relative height, that is relief dissection is in correlation with inclination and represents an additional indicator of strength and intensity of exogenous morphological 
S. Lozić, B. Fürst-Bjeliš, D. Perica - Quantitative-geomorphological and Environmental-historical Impact on the Ecological Soil Depth; Northwestern Croatia

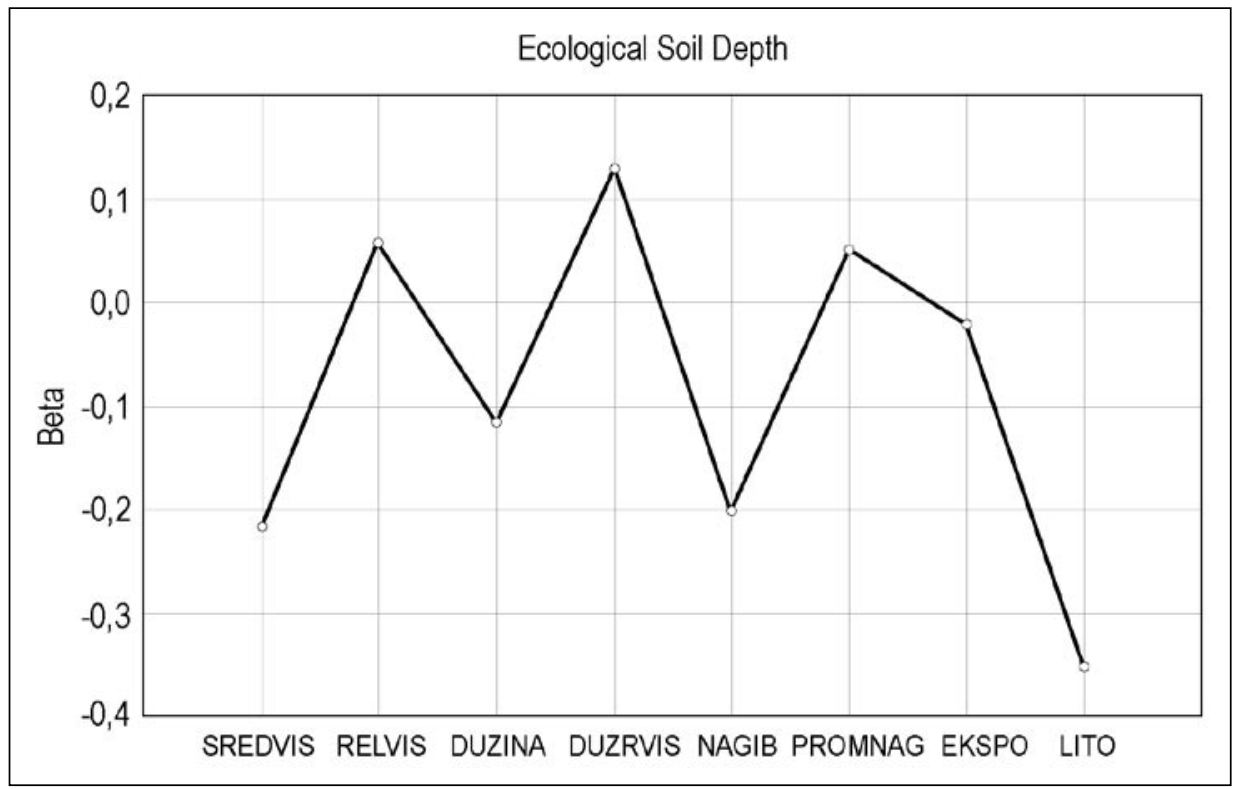

Fig. 4 North-Western Croatia - beta coefficients

Sl. 4. Sjeverozapadna Hrvatska-beta koeficijenti

processes. The correlation direction is positive, which is illogical and contrary to the correlation character with the defined correlation model, because it shows that the soil depth increases with the relative height increase. The reason of this phenomenon probably lies in the lower part of this variable in prediction, as well as in the share of the whole system unexplained variance.

The surface regularity parameter which represents the number of changes of slope inclinations, as the assessor of the geological structure influence, but also of the hypothetic surface outflow character (evenly or unevenly), has a relatively small share (of positive direction) in the ecological depth estimate, which does not mean that it has no greater influence on other soil parameters which are not considered here (structure, texture, rockiness, skeleton condition, retention capacity for excess water, level of draining (drained condition etc.).

Exposition index on the level of the whole area is not in a significant correlation with ecological depth for several reasons. As regression analysis is the indicator of the relative share of variables in prediction, it is evident that on this research level other variables included in the analysis have a much greater influence on the soil depth variability. We should also take into consideration the unexplained variance share which indicates that we should pay attention to the a priori unknown influence of the variables which are not in the model. We must also point out an important fact that the regression model as the model of the North-Western Croatia's slope system in entirety represents the average of regression models of mesoregions` subsystems, and this fact should be taken into account in the results` interpretation (Lozić, 2000). 
North-Western Croatia's mesoregion subsystems according to the regression coefficients $(\mathrm{R})$ and determination coefficients $\left(\mathrm{R}^{2}\right)$ are represented in the Fig. 5. It is noticeable that the prediction of the ecological soil depth is the greatest in the regression models for the Moslavačka Mountain $\left(\mathrm{MO}, \mathrm{R}=0.849, \mathrm{R}^{2}=0.720\right)$, Macelj Mountain Range (MA, $\left.R=0.795, R^{2}=0.633\right)$ and Ivančica Mountain (IV $\left.00.719, R^{2}=0.517\right)$.

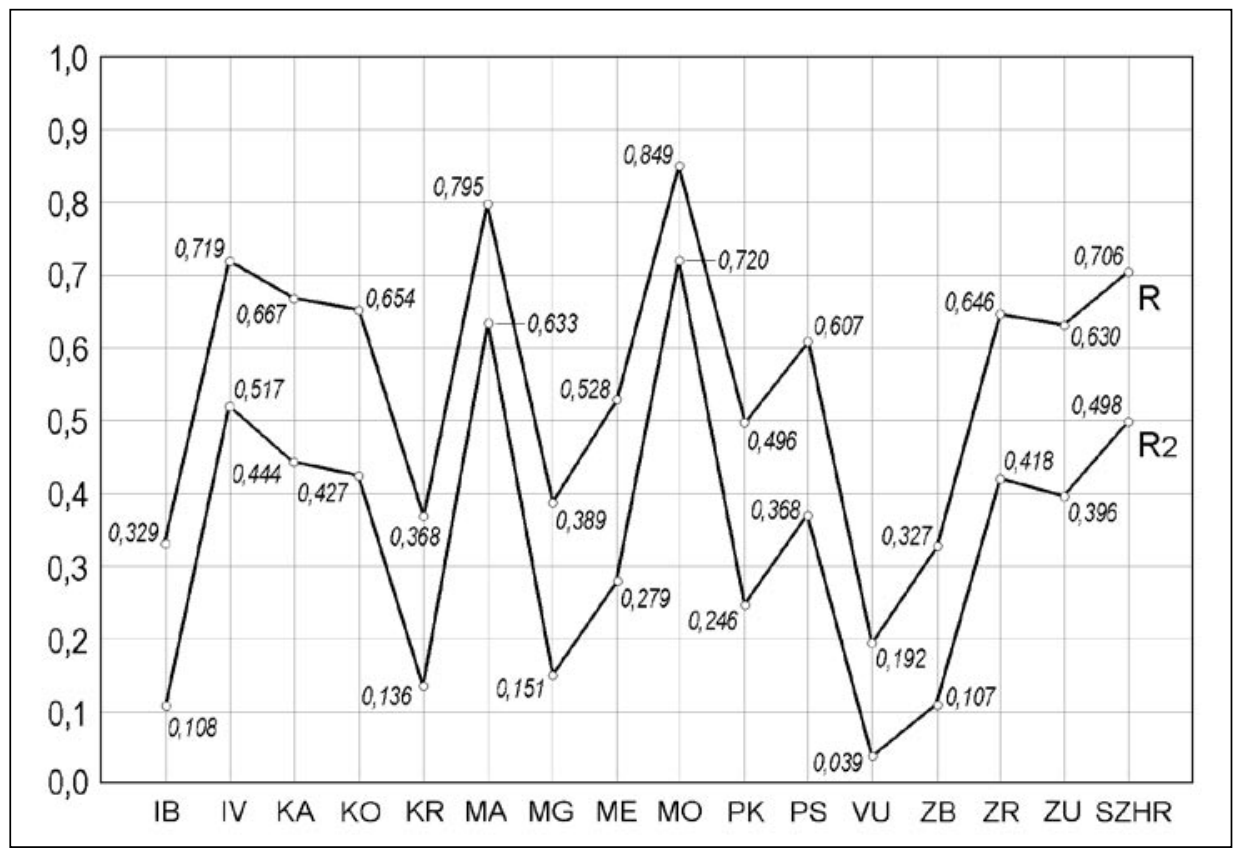

Fig. 5 Regression coefficients and determination coefficients according to mesoregions Sl. 5. Regresijski koeficijenti i koeficijenti determinacije prema mezoregijama

Comparison of mesoregions according to the standardised beta coefficients points to specific differences in the share of variables on the prediction of the ecological soil depth among mesoregions, which indicate the existence of regional differences in the volume and intensity of the exomorphological processes`activity. Regarding great variability of regression and determination coefficients, we shall consider in more detail the relation features of variables on Ivančica and Strahinčica (IV), Macelj Mountain Range (MA) and Moslavačka Mountain (MO), where the highest regression and determination coefficients have been determined within the regression models.

On Ivančica, the variables of inclination, lithology and average height with negative signs account for the largest share in ecological depth determination. On the Macelj Mountain Range the index variables of length, relative height, lithology and inclination account for the greatest share in prediction. On the Moslavačka Mountain those are the variables of lithology and average height. A relatively significant share of the slope length variable (of negative sign) on prediction has been determined on all elevations. Regarding the results of the most representative regression models, we can affirm that out of the variables included in the 
analysis, the variables of lithology, average height and inclination account for the greatest share in ecological depth prediction, which corresponds to the average for the researched area and is identical with the correlation analysis results. The features of correlation between the exposition index and ecological depth are interesting, because the correlation is positive in all three models, which confirms the initial assumption about the ecological soil depth increase when it is protected from the direct activity of humid air masses.

Regression analyses of other mesoregions, i. e. regression beta coefficients for the independent variable exposition index, show that correlation is significant only for the mesoregions South-Eastern Bilogora (IB), North-Western Bilogora (ZB), Zrinska and Trgovska Mountain (ZR) and Žumberačka Mountain (ZU), with negative direction, which affirms a general trend designed by correlation analysis. With regard to the lower values of the regression and determination coefficient, the determined significance level is questionable, so the results should be taken with reserve. One of possible explanations of the negative correlation between the exposition index and ecological soil depth arises from the analysis of relation among variables in entirety, on the basis of which the correlation and regression models show a simultaneous increase of inclination, average height and exposition index, and in reverse. Inclinations on the slopes of a higher exposition index, which are to a lesser extent exposed to the precipitation destructive activity, have higher values of inclination and average height, which is reflected on a lesser ecological soil depth, and in reverse. The quoted phenomenon points to a possible assumption about a long-lasting activity of morphological processes, especially of precipitation on the relief formation. Namely, a more intensive precipitation activity on the slopes of a lower exposition index (exposed to a stronger influence of precipitation), and in that connection transportation of the slope material from the higher to lower parts of the slope, could have caused a gradual lowering of the relief and lessening of inclinations, and consonant with that, the soil depth increase.

Besides the mentioned reasons, the negative correlation between exposition and ecological depth can be caused by relief structural material, e.g. on Bilogora, which is elongated in the direction NW-SE, and its north-western slopes are much more steeply placed than the south-western ones. This situation can be the cause of a greater ecological soil depth on usually climatically unfavourable slopes exposed towards the south, southeast, south-west and west.

Correlation between the exposition index and ecological soil depth is hard to be generalised with regard to the share of the unexplained variance of the model in entirety, as well as when there are big differences in the degree of variances explained by regression at the level of mesoregions `subsystems. However, regarding the positive correlation determined inside several regression models with high shares of the explained variance, it is possible to affirm the assumption about enlargement of the ecological soil depth with the sheltered condition of humid air masses, although there is a greater or smaller influence of some other factors which are not included into the analysis, e. g. of endogenous geological processes and vegetation cover, which makes the interpretation difficult. We also think that the form and a relative long duration of human impact are one of the important factors influencing the variability of the ecological soil depth, which make a considerable part in the share of the unexplained model variance. 
It would be necessary to carry out a more detailed analysis of these problems on the basis of smaller areas ' research with an obligatory inclusion of the additional quantitative geomorphological and pedological variables, variables of geological structure and vegetation cover, as well as human impact analysis.

\section{CONCLUSION}

With regard to all quoted facts, we can conclude that on the basis of the regression analysis results for the area of North-Western Croatia based on the quantitative geomorphological variables and lithology in entirety, it is possible to give a general estimate of the variability of the ecological soil depth and risk of the slope processes 'negative activity connected with it. In the framework of that estimate the significance of the variables of a lower significance degree must be taken with a grain of salt.

Moreover, regarding the basic principles of the relation between man and environment, as well as various models of soil evaluation and direct consequences of human impact, the significance of that impact for the variability of the ecological soil depth is undeniable.

NOTES

1. The majority of spatial samples is markedly complex and it is the result of interrelation of a larger number of variables, among which many are not included into the analysis. So, in many geographical analyses based on regression a significant unexplained variability is present. It is reflected by residual values. Residual values only partly reflect the unexplained variance, because in the cases when the correlative connection among variables is high, a mistake in sampling results with deviations of the noticed values from the regression direction (L. J. King, 1969).

2. Strength on pressure is the result of one-axis load per area unit until the sample fracture. One-axis strength on pressure is calculated according to the expression $\beta_{\mathrm{tl}}=\mathrm{F} / \mathrm{A}$ [MPa]

where $\beta_{\mathrm{d}}=$ strength on pressure (MPa), $\mathrm{F}=$ force which has led to the sample fracture $(\mathrm{MN})$, and $\mathrm{A}=$ sample area on which the force has acted $\left(\mathrm{m}^{2}\right)$, Šestanović, 1993.

\section{BIBLIOGRAPHY}

Allison, R. J., 1996: Slopes and slope processes, Progress in Physical Geography 20,4, E. Arnold, London, $453-465$

Antonić, O., 1996: Modeli utjecaja topoklime na vegetaciju krša, Disertacija, PMF - Biološki odsjek, Zagreb

Bárány, I., Mezósi, G., 1995: Ecological characteristics of doline types in Aggtelek hills (North Hungary), Acta Geographica, T. XXXIV, Szeged, 135-146

Barsch, H., Weisse, R., 1991: Recent Changes of Relief and Soils in the Havel Region Wet of Potsdam, Z. Geomorph. N.F. Suppl.-Bd. 83, Berlin-Stuttgart, 47-52 
S. Lozić, B. Fürst-Bjeliš, D. Perica - Quantitative-geomorphological and Environmental-historical Impact on the Ecological Soil Depth; Northwestern Croatia

Bognar, A., 1980: Tipovi reljefa kontinentskog dijela Hrvatske, Spomen zbornik 30 obljetnice GDH, GDH, Zagreb

Bognar, A.,1999: Geomorfološka regionalizacija Hrvatske, Acta Geographica Croatica, Vol. 34., Geografski odsjek PMF, Zagreb, 7-29

Bovis, M. J.,1993: Hillslope geomorphology and geotechnique, Progress in Physical Geography 17,2, E. Arnold, London, 173.-189.

Brooks. S. M., Richards, K. S., Anderson, M. G., 1993: Approaches to the study of hillslope development due to mass movement, Progress of Physical Geography, 17/1, E. Arnold, London, 32-49

Butlin, R.A., Roberts, N., 1995: Ecological Relations in Historical Times, Blackwell, Oxford.

Carson, M. A., Petley, D. J., 1970: The existence of Threshold Hillslopes in the Denudation of the Landscape, Inst. Brit. Geog., Transactions No. 49, London, 71-94

Matsukura, Y., Hayashida, S., Maekado, A. (1984.) Angles of valley-side slope made of "Shiratsu

DeRose, R. C., 1996: Relationships between slope morphology, regolith depth, and the incidence of shallow landslides in eastern Taranaki hill county, Z. Geomorph. N.F. Suppl.-Bd. 105, Berlin-Stuttgart, 49-60

Doornkamp, J. C., 1993: Clay shrinkage induced subsidence, The Geographical Journal, Vol. 159., No. 2., Royal Geographical Society, London, 196-202

Fuerst-Bjeliš, B., 1996: Historijsko-geografska analiza prostornog pojma tradicionalne regije Turopolja, Doktorska disertacija, Prirodoslovno-matematički fakultet, Sveučilište u Zagrebu, Zagreb.

Gardner, T., Sasowsky, K.C., Day, R.L., 1990: Automated extraction of geomorphometrics properties from digital elevation data, Z. Geomorph. N.F., Suppl.-Bd. 80., Berlin-Stuttgart, 57-68

Geografija SR Hrvatske, 1974: Knjiga 1, Središnja Hrvatska, Školska knjiga, Zagreb

Harvey, A. M., Calvo-Cases, A., 1991: Process Interactions and Rill Development on Badland and Gully Slopes, Z. Geomorph. N.F. Suppl.-Bd. 83, Berlin-Stuttgart, 175-194

Head, L., 2000: Cultural Landscapes and Environmental Change, Key Issues in Environmental Change, pp 179, Arnold, London.

Ibánez, Pérez-González, Jiménez-Ballesta, Saldana, A., Gallardo-Díaz, J., 1994: Evolution of fluvial dissection landscapes in mediterranean environments. Quantitative estimates and geomorphological, pedological and phytocenotic repercussions

Jones, D. C., 1993: Slope instability in a warmer Britain, The Geographical Journal, Vol. 159., No. 2., Royal Geographical Society, London, 196-202

Julian, M., 1991: Rockslides and Water Infiltration: Three Typical Examples from the French Western Alps, Z. Geomorph. N. F., Suppl.-Bd. 83, Berlin -Stuttgart, 127-134

King, L. J., 1969: Statistical analysis in geography, Prentice - Hall, Englewood cliffs, N.Y., 259 p.

Lozić, S., 2002: Kvantitativne geomorfološke značajke Sjeverozapadne Hrvatske, Disertacija, Geografski odsjek PMF-a, Zagreb, 250 str.

Mannion, A. M., 1995: Agriculture and Environmental Change, Temporal and Spatial Dimensions, Chichester.

Mihalić, S., Stanić, B., 1995: Pokreti na padinama - hazard i rizik, 1. Hrvatski geološki kongres, Zbornik radova 2, Opatija, 367-372

Namjenska pedološka karta RH, 1: 300 000, autori: Bogunović, M., Vidaček, Ž., Racz, Z., Husnjak, S., Sraka, M., Agronomski fakultet, Zavod za pedologiju, Zagreb, 1996.

Oguchi, T., 1996: Late Quaternary hillslope erosion rates in Japanese mountains estimated from landform classification and morphometry, , Z. Geomorph. N.F., Suppl.-Bd. 106, Berlin-Stuttgart, 169-181

Otorepec, S., 1980: Agrometeorologija, Nolit, Beograd. 
Pallister, J. W., 1956: Slope development in Buganda, Geographical Journal, Vol CXXII, Part 1, London, $80-87$

Powell, J.M., 2000: Historical Geographies of the Environment, u: Graham, B, Nash, C. (ed.): Modern Historical Geographies, Longman, London.

Prasuhn, V., Schaub, D., 1991: The Different Erosion Dynamics of Loess and Clay Soils and the Consequences for Soil Erosion Control, Z. Geomorph. N. F., Suppl.-Bd. 83, Berlin -Stuttgart, 127-134

Rouse, C., Styles, P., Wilson, S.A., 1991: Acoustic Emissions from two Landslip Areas in South Wales, Z. Geomorph. N.F. Suppl.-Bd. 83, Berlin-Stuttgart, 135-154

Serdar, I., Šošić, D., 1993: Uvod u statistiku, Školska knjiga, Zagreb

Simmons, I.G., 1996: Changing the Face of the Earth, Culture, Environment, History, 2nd. Ed., Blackwell, Oxford.

Simmons, I.G., 1998: Towards an Environmental History of Europe, in: Butlin, R.A., Dodgshon, R.A. (ed.): An Historical Geography of Europe, Clarendon Press, Oxford.

Simmons, I.G., Mannion, A.M. (eds), 1995: The Changing Nature of the People-Environment Relationship: Evidence from a Variety of Archives, Prag.

Šegota, T., Filipčić, A., 1996: Klimatologija za geografe, Školska knjiga, Zagreb, 471 str

Šestanović, S., 1993: Osnove inženjerske geologije, GEING, Split

Vandaele, K., Poesen, J., Marques de Silva, J. R., Govers, G., Desmet, P., 1992: Assesment of factors controlling ephemeral gully erosion in Southern Portugal and Central Belgium using aerial photographs, Z. Geomorph. N.F. 41/3, Berlin-Stuttgart, 273-287

Williams, M., 1994: The Relations of environmental history and historical geography, Journal of Historical Geography, 20, 1 (3-21), Academic Press.

Williams, M., 2000: Dark ages and dark areas: global deforestation in the deep past, Journal of Historical Geography, 26, 1 (28-46), Academic Press.

\title{
SAŽETAK
}

\section{Kvantitativno-geomorfološki i historijsko-geografski utjecaji na ekološku dubinu tla; Sjeverozapadna Hrvatska}

\author{
S. Lozić, B. Fürst-Bjeliš, D. Perica
}

Cilj ove analize je odgovor na pitanje da li su i u kolikoj mjeri nezavisne varijable značajni procjenitelji vjerojatnosti učestalije pojave derazijskih procesa na temelju sadašnjeg stanja, za koje se pretpostavlja da ih odražava zavisna varijabla ekološke dubine tla.

Kako je već navedeno u uvodnom dijelu, metoda multiple linearne regresije u ovom radu je korištena kao kriterij utvrđivanja značajki povezanosti među varijablama i relativne važnosti utjecaja varijabli na predikciju ekološke dubine tla, uz pretpostavku da varijable značajno utječu na opseg i intenzitet egzogenih morfoloških procesa, što se odražava na značajke tla. 
Iz navedenog proizlaze dva važna cilja ove analize: a) utvrđivanje razine signifikantnosti odabranih varijabli, na osnovi čega se donosi odluka da li će se sve varijable koristiti u analizi (odnosno u eventualnim daljnjim analizama) b) određivanje apsolutne i relativne važnosti pojedinih varijabli kao indikatora karaktera, opsega i intenziteta određenih procesa u morfološkom oblikovanju reljefa. To se u ovom slučaju odnosi na predikciju ekološke dubine tla, što može biti od koristi pri eventualnoj kasnijoj evaluaciji kao dodatni kriterij, osobito u slučajevima kada se javljaju određene dvojbe oko razvrstavanja tipova reljefa u određene vrijednosne kategorije.

Intenzitet utjecaja na tlo kroz polikulturni oblik ratarstva i vinogradarstvo, odnosno oranje, zasijecanje padina, te krčenje šume u značajnoj mjeri utječe na proces erozije tla, kao i premještanje padinskog materijala iz viših u niže dijelove padina, te tako uvjetuje varijabilnost ekološke dubine tla.U ovim je, dakle, područjima faktor ljudskog utjecaja na ekološku dubinu tla svakako jedan od značajnijih, te je sasvim sigurno varijabla koja čini znatan dio u udjelu neobjašnjene varijance.

Regresijska analiza za ovisnu varijablu ekološke dubine tla za Sjeverozapadnu Hrvatsku (Tabl.1) rezultirala je relativno visokim regresijskim koeficijentom $(0.705)$ i koeficijentom determinacije $\mathrm{R}^{2}=0.5$. To znači da je regresijskim modelom objašnjeno oko $50 \%$ varijance sustava padina Sjeverozapadne Hrvatske. Značajno je da su sve varijable uvrštene u analizu značajni procjenitelji ekološke dubine tla, osim varijable indeks ekspozicija ( $\mathrm{t}$ - test značajnosti regresijskih koeficijenata uz $\mathrm{p}<0.05)$, s tim da je predznak standardiziranog beta koeficijenta indikator smjera povezanosti.

Analiza odnosa rezidualnih i modelom procijenjenih vrijednosti (devijacija pojedinih točaka od regresijskog pravca) ukazuje na približno linearni odnos između zavisne i nezavisnih varijabli.

Navedeni rezultati regresijske analize za područje Sjeverozapadne Hrvatske omogućili su generalnu procjenu varijabilnosti ekološke dubine tla i s njom povezanog rizika od negativnog djelovanja derazijskih procesa, u okviru koje s rezervom treba uzeti značaj varijabli nižeg stupnja signifikantnosti.

Također, s obzirom na osnovne principe odnosa čovjeka i prirodne sredine, kao i regionalno različite modele vrednovanja tla i neposredne posljedice ljudskog utjecaja neosporan je njegov značaj na varijabilnost ekološke dubine tla.

Received (Primljeno): 2006 - 01 - 16

Accepted (Prihvaćeno): 2006 - 03 - 06

Dr. sc. Sanja Lozić

Gupčeva zvijezda 2, Zagreb, Hrvatska/Croatia

Dr. sc. Borna Fürst-Bjeliš, izv. Prof.

Geografski odsjek, Prirodoslovno-matematički

fakultet, Marulićev trg 19/II, Zagreb,

Hrvatska/Croatia

Dr. sc. Dražen Perica, doc.

Odjel za geografiju Sveučilišta u Zadru,

Ulica Franje Tuđmana 24, Zadar,

Hrvatska/Croatia 
